РЕГУЛЯТОРНА ФУНКЦІЯ ДЕРЖАВИ У ТРАНСФОРМАЦІЇ СУЧАСНИХ УПРАВЛІНСЬКИХ ПІДХОДІВ ЩОДО ПЕДАГОГІЧНО-ВИХОВНИХ ПРОЦЕСІВ У НАЦІОНАЛЬНІЙ ГВАРДІї УКРАЇНИ

\title{
REGULATORY FUNCTION OF THE STATE IN THE TRANSFORMATION OF MODERN MANAGEMENT APPROACHES TO PEDAGOGICAL AND EDUCATIONAL PROCESSES IN THE NATIONAL GUARD OF UKRAINE
}

Проаналізована практика життєдіяльності колективів частин національної гвардії часто демонструє невідповідність вимогам, які встановлені в організації військовоі служби, неуважність до внутрішньої атмосфери. Також існують організаційні патологіі в керівництві колективом, коли командир керує за своїми вигаданими правилами, а це може призвести до конфоліктних ситуацій, взаємної протидії службовців національної гвардії на різних рівнях. У колективах національної гвардії, там, де немає згоди й взаєморозуміння, нагнітається нездорова атмоссрера, присутні соціальні конфрлікти $\breve{~ и ̆ ~ п с и х о л о г і ч н а ~ н е с у м і с н і с т ь, ~ а ~ о т ж е, ~ т а к і ~}$ підрозділи не зможуть фрахово та якісно й у встановлений строк виконати поставлені перед ними службові завдання.

Педагогічна профрілактика соціальних конфрліктів у взаєминах нацгвардійців у процес їхньої спільної діяльності полягає в цілеспрямованому й організованому процесі управлінського впливу педагогічно-виховних фракторів і посадових осіб, які могли б істотно впливати й збільшувати ефективність виконуваних особовим складом службових завдань. Це можливо реалізувати шляхом вдосконалення психолого-педагогічної підготовки посадових осіб до педагогічної профрілактики соціальних конфрліктів, розвитку діагностування та прогнозування сочіальних конфрліктів, а отже, оптимізації педагогічної профрілактики соціальних конфрліктів у колективах національної гвардії.

В основі будь-якого соціального конслікту лежить ситуація, що містить або суперечливі позиції сторін з якого-небудь приводу, або протилежні цілі й засоби їх досягнення, або розбіжність інтересів і бажань партнерів. Розглядаючи перебіг різного роду соціальних консрліктних ситуацій, бачимо, що базою суперечностей у соціальному інциденті вважається коло інтересів, погляди співучасників соціального інциденту, переслідувані ними місії, прагнення, психологічна несумісність, а також громадські, цивілізаційні, персональні характерні риси конкретної особистості.

Попередження соціальної конорліктної ситуації в лавах національної гвардії України, так само як різних конфрліктних зіткнень у середовищі службовців національної гвардіі в иілому, дає можливість накопичити для подальшого аналізу велику кількість різних випадків на соціальній основі, сформувати банк соціальних конфрліктів, який буде можливо розглядати з метою попередження та знайдення управлінських підходів із педагогічно-виховного впливу, запобігання та розв'язання ймовірних консрліктів у колективах національної гвардіі.
Ключові слова: регуляторна фрункція, управлінські підходи, сучасний етап, педагогічно-виховні фрактори, трансформація, національна гвардія.

The analyzed practice of life of the National Guard often demonstrates non-compliance with the requirements set in the organization of military service, inattention to the internal atmosphere. There are also organizational pathologies in the leadership of the team, when the commander manages according to his imaginary rules, and this can lead to conflict situations, mutual opposition of employees of the National Guard at different levels. In the teams of the National Guard, where there is no agreement and mutual understanding, an unhealthy atmosphere is created, there are social conflicts and psychological incompatibilities, and therefore, such units will not be able to professionally and efficiently and in a timely manner to perform their duties. Pedagogical prevention of social conflicts is a purposeful and organized process of managerial influence of pedagogical and educational factors and officials, aimed at pedagogical prevention of social conflicts in the relations of the National Guard in the process of their joint activities, which could significantly influence and increase the effectiveness of personnel.

This is possible due to the improvement of psychological and pedagogical training of officials for pedagogical prevention of social conflicts, the development of diagnosis and prediction of social conflicts, and hence the optimization of pedagogical prevention of social conflicts in the National Guard. At the heart of any social conflict is a situation that involves either conflicting positions of the parties on any issue, or opposing goals and means to achieve them, or a divergence of interests and desires of partners. Considering the course of various social conflict situations, we see that the basis of contradictions in a social incident is the range of interests, views of the participants of the social incident, their missions, aspirations, psychological incompatibility, as well as social, civilizational, personal characteristics of a particular individual.

Prevention of social conflict in the ranks of the National Guard of Ukraine, as well as various conflict clashes among employees of the National Guard in general, makes it possible to accumulate for further analysis a large number of different cases on a social basis, to form a bank of social conflicts that can be considered to prevent and finding managerial approaches to pedagogical and educational influence, prevention and resolution of possible conflicts in the National Guard.

Key words: regulatory function, managerial approaches, modern stage, pedagogical and educational factors, transformation, national guard. 
Постановка проблеми в загальному вигляді. Закономірності й суперечності створюють розуміння того, як і в якому напрямі мають розвиватися та рухатися педагогічні технології запобігання соціальним конфліктам. Під принципами педагогічної профілактики соціальних конфліктів у колективах національної гвардії доречно вирізняти ключові керівні положення, що характеризують їх організацію, сутність і методологію. Профілактика конфліктних соціальних зіткнень у підрозділах національної гвардії встановлює певні вимоги до процесу, який містить методи, прийоми, засоби й форми.

Попереджувальна діяльність відіграє важливу роль у ході педагогічної та виховної роботи. Профілактика соціальних конфліктів уособлює використання різних методів, що значною мірою зумовлюється особливістю конфліктних соціальних взаємовідносин та особливими рисами його співучасників. Запобігання та розв'язання соціальних конфліктів у національній гвардії України обов'язково ґрунтується, зокрема, на обліку його суті й змісту, характері суперечностей, цілеспрямованості, психологічних станах з урахуванням динамічності процесу.

Аналіз останніх досліджень і публікацій. Для розвитку й формування нацгвардійця необхідні відповідне середовище й професійна діяльність, яка буде формувати державно-патріотичну спрямованість нацгвардійця. Під час розгляду проблеми важливим $€$ запобігання та подолання соціальних конфліктів у частині національної гвардії як організованого й цілеспрямованого процесу впливу командира на підвищення ефективності в системі управління та виховання особового складу.

Аналіз соціальних конфліктів, що відбувалися в колективах національної гвардії, показує, що типовими серед них $€$ конфлікти, пов'язані з протидією між дисциплінованими нацгвардійцями й тими, що виявляли в якомусь конкретному випадку елементи непорядності, боротьбою за соціальний статус у колективі, а також із розв'язанням проблем конфлікту суперечностей між новаторами й консерваторами. Командиру необхідно пам'ятати, що непорядні вчинки, яких припускаються службовці національної гвардії будь-якої категорії, завжди несуть у собі зародок соціального конфлікту між тими, хто допускає подібні вчинки, й дисциплінованими нацгвардійцями, яких у колективах національної гвардії зазвичай більшість.

Виділення не вирішених раніше частин загальної проблеми. Узагальнений матеріал, зібраний під час вивчення соціальної конфліктної взаємодії в підрозділах націо- нальної гвардії, свідчить про те, що основною ланкою в такому конфлікті є особистість. Розгляд соціально-педагогічної проблематики запобігання та розв'язання соціальних конфліктних ситуацій необхідно здійснювати, виходячи з єдності розуміння сутності цього питання, його істотних ознак.

Нездатність на ділі регулювати соціальні зіткнення, психологічну несумісність, вибирати раціональні прийоми їх запобігання та розв'язання негативно позначається на організації виховного процесу й ділової готовності підрозділів національної гвардії. Попереджувальна діяльність посадових осіб частин і підрозділів національної гвардії з урахуванням педагогічно-виховних факторів має полягати у виробленні профілактичних функцій, принципів і закономірностей процесу виховання службовців національної гвардії.

Мета статті полягає в обґрунтуванні управлінських підходів щодо трансформації формування сучасних педагогічно-виховних факторів проходження служби в національній гвардії України.

Виклад основного матеріалу. Під колективом розуміють групу людей, які пов'язані між собою спільною діяльністю, спільністю цілей, поглядів, норм, правил поведінки, засобів діяльності й взаємно впливають один на одного. У житті, розвитку й діяльності кожної людини колектив відіграє вирішальну роль. у ньому формується соціально-психологічне обличчя особистості, а колектив національної гвардії - це форма об'єднання службовців національної гвардії в групу для спільного розв'язання службових завдань.

Основними знаковими особливостями колективу національної гвардії $€$ те, що він будується на основі єдиноначальності, де безперервно проводяться інформаційна й виховна робота, службові навчання, є особливі мотиви й цілі діяльності, він знаходиться в постійній діловій готовності. Сприйняття суті проведення педагогічної профілактики інцидентів у колективах національної гвардії пояснює її сутність, структуру й особливий вид структурних компонентів. Під структурою розуміється сутність і розміщення його компонентів, методів взаємозв'язків і взаємодій між ними, що утворюють єдине психолого-педагогічне навчання та розвиток, зумовлені деякими критеріями.

Конструкція процесу профілактики соціальних інцидентів в колективах національної гвардії передбачає присутність суб'єкта й об'єкта, чітко встановлених цілей і проблем, змісту, функцій, закономірностей, суперчностей, принципів, способів, прийомів, конфігурацій і знарядь здійснення, типів попереджувальної 
роботи та їі результатів, а крім того, шляхів та обставин, що впливають на результативність цього процесу [4]. Компонентами процесу педагогічної профілактики соціальних інцидентів серед особового складу є суб'єкти й об'єкти педагогічної профілактики.

Реалізуючи процедуру профілактики, суб'єкти попереджувальної роботи проявляють багатосторонній вплив у злагоді з опонентами суперечливої взаємодії, а також на психологічний настрій особового складу підрозділу для того, щоб досягти позитивних результатів в їх діях, а крім того, у випадку потреби змінюють попереджувальну роботу з метою найуспішнішого її впливу. Визначаючи складність і суперечливість цього процесу, основними елементами педагогічної профілактики соціальних конфліктів у підрозділах і в національній гвардії загалом визнаються конкретні, підготовлені в професійному відношенні посадові особи.

Проаналізувавши наявні підходи, необхідно сформулювати цілі й завдання педагогічної профілактики або ввести відповідні зміни до вже наявних, скорегувати їх в наступні превентивні дії та вплив на суб'єктно-об'єктні відносини профілактики соціальних конфліктів у колективах національної гвардії. Здійснення педагогічно-виховних факторів компенсує функції сприяння виробленню в нацгвардійців бажання поміняти негативні форми поведінки на позитивні. Реалізація функції корекції уособлює використання різних способів, засобів і форм, що забороняють або ліквідують негативні індивідуальні властивості.

Роль спонукання до самоврядування може допомогти створювати й вдосконалювати прагнення коригувати свої мінуси, розвивати негативне ставлення до них. Слід виокремити, що всі без винятку функції розвитку педагогічної профілактики соціальних інцидентів в умовах служби в національній гвардії взаємопов'язані й виражаються в єдиному розумінні процесу. Реалізація таких функцій допоможе забезпечити згуртованість колективу національної гвардії, виключити появи соціальних конфліктних ситуацій у взаємодії нацгвардійців.

Головними закономірностями, котрі впливають на розвиток і діяльність запобігання соціальних зіткнень у підрозділах, де функціонують майже всі без винятку закономірності педагогічної діяльності, є єдині закони й закономірності соціального формування, а крім того, характерні закони й закономірності самої педагогічної діяльності в національній гвардії [1]. Перераховані закономірні зв'язки процесу педагогічної профілактики соціальних конфліктів у колективах національної гвардії зумовлені зовнішніми зв'язками.
Як показує практика, наявні взаємозв'язки в глибинній течії педагогічної профілактики приводять до наявності своєрідних, безпосередньо попереджувальних логічних взаємозв'язків. Усі без винятку закономірності педагогічної профілактики соціальних конфліктів у середовищі національної гвардії, маючи різновиди стабільних логічних взаємозв'язків, встановлюють першорядні шляхи підвищення ефективності попереджувальної діяльності командирів органів оперативного управління відповідних підрозділів.

Джерела реалізації та підвищення ефективності процесу педагогічної профілактики соціальних конфліктів у колективах національної гвардії зумовлюються суперечностями, котрі виникають, узагальненням та аналізом об'єктивної інформації та науково обґрунтованих положеньтакогопроцесу [2]: зростаннямвимог до нацгвардійців, новими, постійно змінюваними умовами проходження служби в національній гвардії та застарілими способами й умовами навчання та виховання; суперечностями між результативністю процесу профілактики соціальних конфліктів і недостатнім рівнем конфліктної компетенції командування та посадових осіб підрозділів національної гвардії, рівнем загальної культури нацгвардійців.

У зв'язку із цим розв'язувати проблеми потрібно спільними зусиллями, а не тільки зусиллями командирів та офіцерів органів по роботі з особовим складом. Долаючи різноманітні проблеми, в ході навчання та виховання особистість нацгвардійця формується та розвивається, підтримуються ті якості, які сприяють безконфліктній поведінці під час проходження служби. Мета педагогічної профілактики зводиться до того, щоб сприяти розвитку позитивних процесів і скоротити неминуче утворювані суперечності.

Педагогічна профілактика як систематичний та організований педагогічний процес управлінського впливу посадових осіб спрямований на педагогічну профілактику соціальних конфліктів у взаєминах національних гвардійців у ході їхньої спільної діяльності й підвищення ефективності виконуваних особовим складом службових завдань на основі психолого-педагогічної підготовки посадових осіб та оптимізації технології педагогічної профілактики в колективах національної гвардії.

Успіх у діяльності командирів та їх заступників на лавах національної гвардії по роботі з особовим складом визначається головним чином їхньою компетентністю, професійною та психолого-педагогічною підготовленістю. У сучасних умовах керівництву й офіцерам не обійтися без розуміння законів, за якими скла- 
дається та протікає життя колективів національної гвардії. Аналіз якісних показників нацгвардійців показав, що їхні соціально-психологічні характеристики щорічно покращуються, що пов'язано з ростом престижу служби на лавах національної гвардії.

Молоді люди, як правило, йдуть служити на лави національної гвардії за власним бажанням із глибоким переконанням у тому, що за час служби в національній гвардії вони отримають нові знання, навчаться поводитися з відповідним озброєнням. В умовах швидкоплинності подій, що відбуваються в сучасному суспільстві, існує певний ліміт часу на підготовку підрозділів до виконання службових завдань.

У цих умовах особливої актуальності набуває завдання досягнення найвищого рівня службової готовності у встановлені строки й наявними силами. Водночас виникає проблема прискорення процесів згуртування колективу й підрозділів національної гвардії, розвитку в них безконфліктних соціальних відносин. Розв'язання її можливо шляхом вибору найвигіднішого поєднання сил і засобів із боку досягнення найкращих виховних результатів і мінімуму витрат часу.

Для підтримки здорового морально-психологічного клімату в підрозділах національної гвардії, враховуючи педагогічно-виховні фактори, існує безліч способів для організації попереджувальної діяльності як на етапі адаптації до службових умов, так і в подальшій службі [3]. Організована робота з використанням перерахованих форм і методів дозволить здійснювати соціальну й психолого-педагогічну захищеність національного гвардійця, створить атмосферу доброзичливості, чуйності, взаємодопомоги в підрозділах і в національній гвардії загалом.

Однією із суперечностей сучасної практики $€$ те, що в національній гвардії плануються та проводяться з різними категоріями нацгвардійців навчально-методичні, інструкторсько-методичні заняття з різної тематики, водночас основною причиною виникнення соціальних конфліктів залишається загальна низька культура взаємовідносин національних гвардійців. Для того, щоб за можливості не потрапляти в складні ситуації, необхідно дотримуватися принципу людської вихованості, стриманості.
Висновки. Існує необхідність формування високого рівня загальної та правової культури, професійного й морального обличчя національного гвардійця, зміцнення позитивного іміджу в суспільстві. Необхідно активніше застосовувати нові методики й впроваджувати сучасні методи вивчення індивідуально-психологічних і психофізіологічних особливостей особового складу національної гвардії, соціально-психологічних характеристик колективів, відповідних сучасному стану національної гвардії, а також удосконалювати психолого-педагогічну підготовку посадових осіб, оптимізувати педагогічні технології, спрямовані на профілактику соціальних конфліктів у колективах національної гвардії.

Такі основні позитивні й негативні тенденції виявлені в сучасній практиці реалізації педагогічної профілактики соціальних конфліктів у колективах національної гвардії. Таким чином, на основі результатів сучасної практики педагогічної профілактики соціальних конфліктів у національній гвардії можна зробити висновок про те, що в цілому наявна система профілактики соціальних конфліктів у колективах національної гвардії забезпечує успішне виконання структурами національної гвардії покладених на них завдань, проте не досить своєчасно змінюються підходи, форми й методи щодо запобігання та розв'язання соціальних конфліктів у національній гвардії.

\section{ЛIТЕРАТУРА:}

1. Ковальчук В.Г. Основні принципи сучасної державної гуманітарної політики України. Стратегічні пріоритети. № 4 (25). 2012. С. 18-21.

2. Павлюк К.С. Діяльність неурядових громадських організацій у контексті забезпечення національної безпеки. Вісник НАДУ. 2012. № 2. C. 210-217.

3. Пироженко В.О. Гуманітарна складова національної безпеки: предмет дослідження та коло основних проблем. Стратегічна панорама. 2005. № 2. C. 37. URL: niss.gov.ua/vydanna/panorama/ issue.php?s=prnb1\&issue=2005_2 (дата звернення: 30.01.2020).

4. Степанко О.В. Сутність, мета, завдання та складові гуманітарної сорери. Теорія та практика державного управління. 2012. Вип. 3. С. 201-208. URL: nbuv.gov.ua/UJRN/Tpdu_2012_3_29 (дата звернення: 30.10.2020). 